\title{
Developing DRTA (Directed Reading Thinking Activity) Strategy Teaching Materials for Elementary School Students in Improving Reading Prediction Skills
}

\author{
Otang Kurniaman ${ }^{1}$, Eddy Noviana ${ }^{2}$, Zufriady 3
}

DOI: $10.35445 /$ alishlah.v13i1.350

\begin{tabular}{l} 
Article Info \\
\hline Keywords: \\
Reading predictions \\
DRTA strategy \\
Learning materials
\end{tabular}

Kata kunci:

Prediksi membaca, Bahan ajar Strategi DRTA

\begin{abstract}
The purpose of this study was to develop appropriate reading teaching materials for use in elementary schools. The study used the $4 \mathrm{D}$ research method by developing reading teaching materials using the DRTA strategy in predicting reading. Several analyzes the defining phase of needs analysis, including curriculum, concepts, and tasks. While in the study of students about the suitability of teaching materials developed with the level of student development. The design phase of teaching material development begins with the design of RPP with the curriculum. The format and preparation of teaching materials are modified from the cover, preface, table of contents, usage instructions, concept maps, competencies to be achieved, tasks, and work instructions. The development phase includes the validation of teaching materials and RPP. Then the product is tested to see the practicality and effectiveness of the teaching materials that have been developed. Research results explained RPP validation for aspects of learning objectives with an average of 94 very valid and aspects of learning material with 100 very valid. The dissemination stage of the assessment process for reading skills is done using an assessment rubric. The average class value at meeting 1 is 93.34 . The second meeting is 89.142 . The third meeting is 85.92 with an overall average of 89.46 with a very good category. The assessed aspects are several student skills, from predicting reading activities, reading techniques, filling in the meaning of words that have not been understood, writing down the main contents of the reading text, and summarizing the summary of the reading contents.
\end{abstract}

\begin{abstract}
Abstrak
Tujuan penelitian ini adalah mengembangkan bahan ajar membaca yang tepat untuk digunakan di sekolah dasar. Penelitian ini menggunakan metode penelitian 4D dengan mengembangkan bahan ajar membaca menggunakan strategi DRTA dalam memprediksi membaca. Tahap define of need analysis dilakukan dengan beberapa analisis yang meliputi kurikulum, konsep, dan tugas. Sedangkan pada analisis siswa tentang kesesuaian bahan ajar dikembangkan dengan tingkat perkembangan siswa. Tahap desain pengembangan bahan ajar diawali dengan
\end{abstract}

\footnotetext{
${ }^{1}$ Universitas Riau, Pekanbaru, Indonesia

Email: otang.kurniaman@lecturer.unri.ac.id

2 Universitas Riau, Pekanbaru, Indonesia

Email: eddy.noviana@lecturer.unri.ac.id

3 Zufriady

Email: zufriady@lecturer.unri.ac.id
} 
desain RPP dengan kurikulum. Format dan penyusunan bahan ajar dimodifikasi dari sampul, kata pengantar, daftar isi, petunjuk penggunaan, peta konsep, kompetensi yang ingin dicapai, tugas, dan petunjuk kerja. Tahap pengembangan meliputi validasi bahan ajar dan RPP, kemudian produk diuji untuk melihat kepraktisan dan keefektifan bahan ajar yang telah dikembangkan. Hasil penelitian menjelaskan validasi RPP untuk aspek tujuan pembelajaran dengan rata-rata 94 sangat valid, dan untuk aspek materi pembelajaran dengan rata-rata 100 sangat valid. Tahapan diseminasi proses penilaian keterampilan membaca dilakukan dengan menggunakan rubrik penilaian. Nilai rata-rata kelas pada pertemuan 1 adalah 93,34. Pertemuan 2 sebesar 89,142, pertemuan 385,92 dengan rata-rata keseluruhan 89,46 dengan kategori sangat baik. Aspek yang dinilai adalah sejumlah keterampilan siswa mulai dari meramal aktivitas membaca, teknik membaca, mengisi makna kata yang belum dipahami, menuliskan isi pokok teks bacaan, dan meringkas rangkuman isi teks bacaan.

\section{INTRODUCTION}

Reading skills play an essential role in life because knowledge is obtained through reading. Therefore, this skill must be mastered from an early age, including in elementary school. Students are expected to acquire literacy skills, namely reading and writing (Nurdiyanto dan Suryanto, 2010). Reading is generally perceived as the process of recognition and comprehension of written or printed materials (Heriyawati, Saukah, \& Widiati, 2018). Teaching reading is a process in learning Indonesian is an interaction between teacher and students through reading texts. It means that the teacher guides students to find information from the text, and students capture the meaning of the text (Hasan, 2017). Reading is a skill that is so complex that it requires concentration. (Harrington \& Sawyer, 1992; Lally, 1998; Miyake \& Friedman, 1998; Saito et al., 1999; Lu \& Liu, 2015). It is a thought process that includes word recognition, literal comprehension, interpretation, critical reading, and creative comprehension.

The factor that causes low reading ability is the schooling system that still lacks literacy opportunities for students. The teaching model in class is too talkative, while students are too challenging to be listeners. Teachers rarely make reading activities a frame of reference in their learning. Besides, the low level of elementary school reading skills is because students receive more memorization lessons than the practice of using language, such as writing (Nazurty et al., 2019). It is under the opinion of (Nurdiyanti \& Suryanto, 2010; Abi \& Kömür, 2018), suggesting that the weakness of Indonesian language teaching lies in emphasizing speaking about language (talk about the language) rather than practicing using language (using language). Based on this statement, it can be concluded that the cause of the low reading skills of students in elementary schools is because students have learned more from memorizing or speaking than writing after reading activities. Using teaching materials in teaching reading is more systematic so that students' predictions are more directed in their understanding (Kurniaman et al., 2018). Reading teaching materials is very important. After all, with these teaching materials, it will be easier for students to read texts and stories in reading learning. The ability of teachers in the field has not been able to develop reading teaching materials. Most teachers still use materials in the textbooks they buy. This teaching material is adjusted to the DRTA strategy (Directed Reading Thinking Activity) by guiding students in understanding reading by reading predictions and developing stories with their predicted results.

The core activities in learning take an essential role in achieving learning goals and informing students who have been established. The core activities in learning comprehension reading are designed under the DRTA strategy (Kurniaman \& Noviana, 2017). The problems above can be stated that the developed teaching materials certainly minimize the problems that arise by looking comprehensively at the needs in the preparation of teaching materials under the development of students (Kurniaman et al, 2018). Reading learning using DRTA strategy teaching materials (Directed Reading Thinking Activity) is made according to the learning steps 1) students predict the title, 2) predict the text through pictures, 3) read the reading text by equating the prediction results, and 4) rewrite the text the reading he reads (Rahim, 2009). Teachers need to develop teaching materials because it can provide convenience in the learning process that is structured according to the learning material (Septyanti, Kurniaman, \& 
Charlina, 2020). Before developing teaching materials, a reading ability test was carried out with the DRTA strategy and conducted trials on implementing DRTA in the learning process (Kurniaman, Noviana, Hermita, \& Charlina, 2019). It can provide benefits to the development of students in reading comprehension in elementary schools.

Ideally, the teaching material used by the teacher should be by the curriculum needs and the reading stages, namely: the preproduction stage includes the activity of predicting the contents of the reading and making questions according to the reading predictions and writing the contents of the reading (Kurniaman, et, al, 2018). The post-reading stage includes summarizing the contents of the reading and answering questions based on the reading contents (Al Odwan, 2012). This study aims to develop teaching materials using the DRTA strategy to see the effectiveness of elementary school learning in predicting reading.

\section{METHODS}

The type of research used in this research is development research. There are terms Research and Development / R \& D which can be translated into research and development. Research and development methods are research methods used to produce specific products and test the effectiveness of these products. Development of research is also interpreted as a systematic study of how to design a product, develop/produce the design, and evaluate the performance of the product, to obtain empirical data that can be used as a basis for making products, tools, and models that can be used in learning or non-learning (Sugiyono, 2015).

Development research can be interpreted as a series of processes or steps to develop a compelling product and learning materials, media, learning strategies to be used in schools, and not test theories (Surya Dharma in Putra, 2015). In this study, researchers developed reading teaching materials with the DRTA strategy (Directed Reading Thinking Activity) based on literacy in grade IV elementary school. The development model used refers to the 4-D model, which consists of 4 stages: defining, designing, developing, and disseminating. The following are explained in developing reading teaching materials with the DRTA strategy in grade IV elementary school.

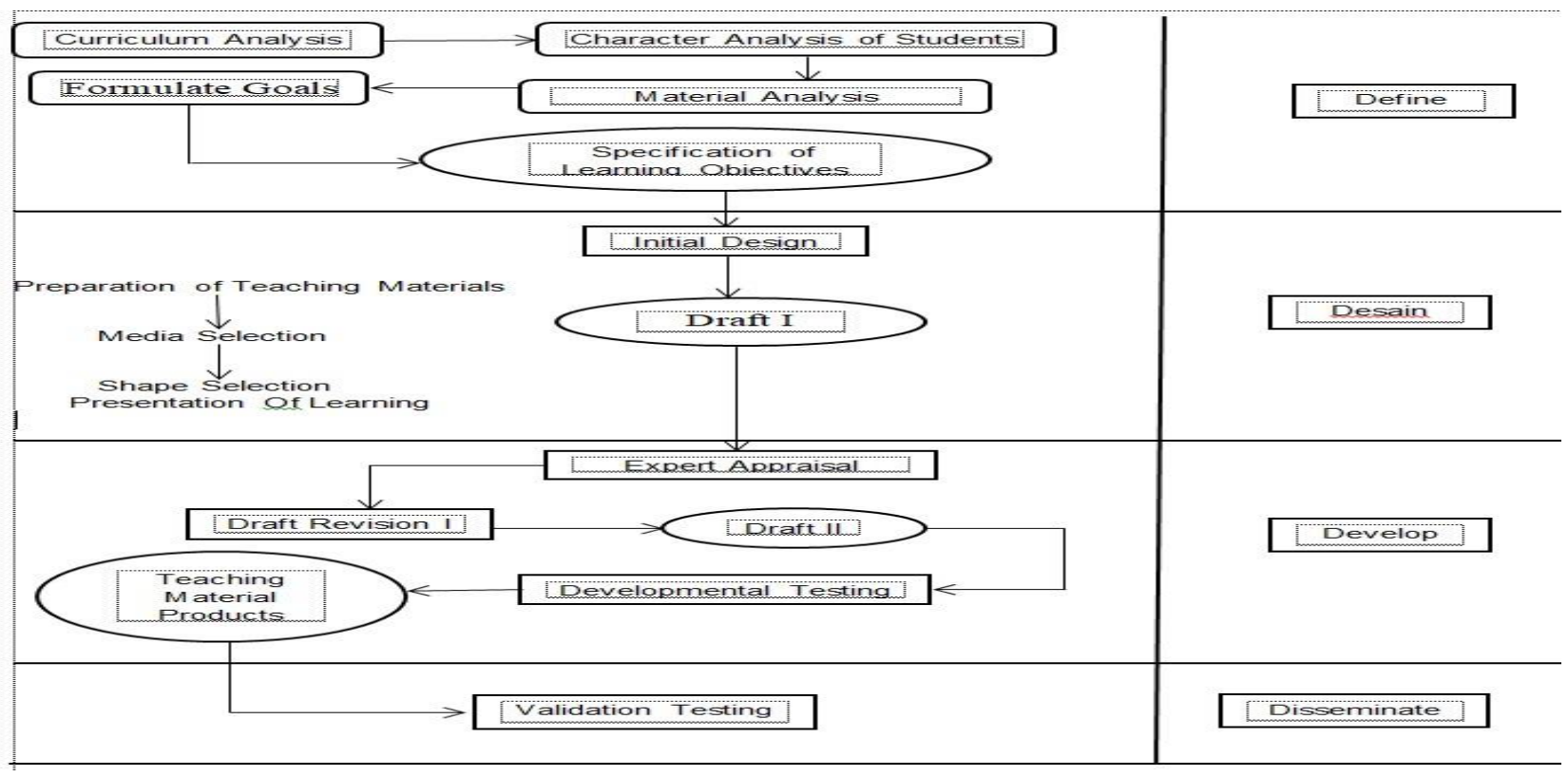

Figure 1. Steps of $4 \mathrm{D}$ research

The framework of thought above described the stages of research on the development of reading teaching materials with literacy-based DRTA strategies in the fourth grade of elementary schools as follows: 


\section{a. Define Stage}

In the context of developing teaching materials, the defining stage is done by:

1) Curriculum analysis

In the initial stage, researchers reviewed the current curriculum, namely Kurikulum Tingkat Satuan Pendidikan (KTSP), and can be developed in the 2013 curriculum. The analysis carried out is useful to determine the competencies that will be developed into a teaching material design. From the analysis results, the researcher establishes essential competencies and makes indicators of learning achievement.

2) Analysis of the characteristics of students

In analyzing the characteristics of students, what is considered by the researcher is the academic ability of the fourth-grade students of elementary school. Concerning the development of this teaching material, the academic skills of fourth-grade students of elementary schools need to be known to compile teaching materials that are under the ability of the fourth-grade students to think.

3) Material analysis

The material analysis identifies the primary material that will be developed, collecting, selecting relevant material, and rearranging it systematically. The researcher chose to use the material in developing reading teaching materials using literacy-based DRTA strategies under the material in grade IV elementary school.

4) Formulate goals

In this stage, the researcher will convert the analysis results at the material analysis stage into a more specific goal of developing reading teaching materials with literacy-based DRTA strategies in grade IV elementary school.

\section{b. Design Stage}

At this stage, the reading instructional materials are designed with literacy-based DRTA strategies. The things that are done at this stage are:

1) Compile a criteria test

The researcher designed the pretest questions as the first action to finding out the students' initial abilities and posttest questions to find out the students' understanding after participating in the learning.

2) Selection of teaching materials that are suitable for the purpose

Researchers use reading teaching materials with literacy-based DRTA strategies that researchers have developed, namely teaching materials. The researcher includes the initial design of teaching materials with literacy-based DRTA strategies. The product, which is the initial design of teaching materials, is called draft I.

3) Selection of the form of presentation of learning

Learning activities will be carried out by following the syllabus guidelines and RPP that the researcher designs. During the learning activities, researchers will use teaching materials with a Literacy-based DRTA strategy that researchers develop.

\section{c. Stage Develop}

Thiagarajan in Mulyatiningsih (2011) explains that there are two activities that researchers must do at this stage of development, namely:

1) Expert appraisal

It is a technique to validate or assess the feasibility of product design or, in this study evaluating the feasibility of teaching materials that researchers have designed. This study involved four validators who mastered the substance about class IV reading ability of elementary schools, learning media, language, and fourth-grade teachers of SDN 79 Pekanbaru. In this study, the validator aims to validate or test the feasibility of class IV reading teaching materials. Validator examines the feasibility of teaching materials from didactic, construction, and technical requirements. It provides advice on 
deficiencies that are still present in teaching materials that aim to refine further the teaching materials that researchers develop.

2) Developmental testing

It is a trial activity of teaching material on the target of the actual subject. In this study, the trial was limited to one class, namely grade IV at SDN 79 Pekanbaru. Before conducting a trial of teaching material products, students are first given a test to determine the student's initial knowledge of the material to be studied. After the test is given a trial product teaching materials are carried out with students observing and discussing the activities in the teaching material. Students fill out the response questionnaire provided by the researcher as an assessment of teaching materials. This trial aims to determine whether the instructional materials developed are suitable for use by fourth-grade elementary school students. After a trial of the product, a second test was conducted to determine the student's understanding of the material that had been studied using the teaching materials that the researchers developed.

\section{c. Stage Disseminate}

Thiagrajan in Mulyatiningsih (2011) divides the dissemination stage into three activities, namely validation testing, packaging, diffusion, and adaption. But at this stage, researchers only conduct validation testing activities. According to Thiagrajan in Mulyatiningsih (2011), at the stage of validation testing, the revised product at the development stage is then implemented on the actual target, aiming to respond to the teaching material that the researcher develops. Dissemination was carried out in class IV at SDN 79 Pekanbaru.

\section{FINDINGS AND DISCUSSION}

This research phase consists of 4 stages consisting of define, design, develop, and disseminate. Each stage must be carried out to establish reading teaching materials with a DRTA strategy to predict reading in elementary school.

\section{Define Stage}

Define stage is a definition by analyzing two aspects, namely analysis of needs and analysis of students. In the needs analysis, several analyzes are carried out covering the curriculum, concepts, and tasks. Whereas in the study of students see the suitability of teaching materials developed with students' level of development. Need analysis is an activity carried out to examine more about various aspects needed to be related to teaching materials to be carried out. Before compiling teaching materials, of course, it must be understood in advance the scope of the material needed and the concepts related to it and the tasks that will be given to students later.

Curriculum analysis is carried out on the learning objectives of the Indonesian language, competency standards (SK), and basic competencies (KD) of Indonesian language subjects, especially reading skills. Curriculum analysis is carried out to see the material, objectives to be achieved from learning, and Indonesian language learning strategies, especially reading skills used in learning. The analysis results are used to develop teaching materials for learning to be under the SK and KD contained in the Indonesian language curriculum about skimming skills in grade IV elementary school. The curriculum used is KTSP. Although curriculum documents cannot wholly represent culturally responsive and pedagogical practices, they could serve as a „window ${ }^{\text {ee }}$ demonstrating the values and knowledge held as necessary in the institution (Sakhiyya, Z., Agustien, H. I. R., \& Pratama, H, 2018).

SK and KD analysis are focused on Indonesian language learning material in grade IV elementary school. As stated in the KTSP, researchers still have not used the 2013 curriculum to develop this teaching material. However, the development of this teaching material can be used in K13 learning, adjusted to the basic competencies and indicators to be achieved. Based on Minister of Education Regulation No. 22 of 2006, the curriculum developed under development principles such as focusing on students' interests and the environment is diverse and integrated, relevant to the needs of life. The decrees taken are 3. They understood the text rather long (150-200 words), instructions for use, 
meaning in the dictionary/encyclopedia. This decree suggests students read texts by reading comprehension. It can take the essence of the text that is read with the correct reading comprehension technique. The proper reading technique is; silent reading, motionless lips or commotion, not moving the head, not pointing a line of reading with a finger or other stationery, and not reading word by word or sentence after sentence.

The main thoughts are ideas/ideas that are the subject of paragraph discussion. The main thoughts are in the main sentence. Usually, the main sentence is at the beginning of the paragraph or the end of the paragraph. Another name for the leading mind is the main points, main ideas, or ideas. In one paragraph, there is only one central thought. Terms of instruction do something; namely, the language used must be short, solid, and innovative. It does not make a double meaning and is logical, directly to the things done. While the language characteristics used are short, solid, and explicit language. The use of young words is understood, is a subtle command sentence. To clarify written instructions, use animation. The order in the instructions must be systematic.

Referring to the things that have been stated previously, further analysis is needed about the needs in developing the teaching materials required by students later. It can be done by interviewing students directly related to the teaching materials used in reading learning. Interviews conducted are unstructured interviews. The interviews conducted do not refer to the interview guidelines, but interviews develop according to students' answers, giving rise to new questions for researchers to explore further information. The interview results between researchers and IVA grade students of SD Negeri 79 Pekanbaru can be seen below.

Table 1. Results of Interviews with Students

\begin{tabular}{cll}
\hline No & \multicolumn{1}{c}{ Question } & \multicolumn{1}{c}{ Student Answers } \\
\hline 1. & Do you like to read? & Yes, I like to read \\
\hline 2. & $\begin{array}{l}\text { What is your opinion about reading } \\
\text { material given by the teacher in the } \\
\text { classroom? }\end{array}$ & $\begin{array}{l}\text { Reading material has few images and is } \\
\text { less attractive }\end{array}$ \\
\hline 3. & Why did you say that? & $\begin{array}{l}\text { Because in the textbook one story one } \\
\text { picture }\end{array}$ \\
\hline 4. & $\begin{array}{l}\text { Oh, I see. Then what kind of interesting } \\
\text { reading text do you think? }\end{array}$ & $\begin{array}{l}\text { An interesting text is a text that has parts } \\
\text { of the story and has a sequence of pictures }\end{array}$ \\
\hline 5. & $\begin{array}{l}\text { So in the textbook, the reading text doesn't } \\
\text { have an image? }\end{array}$ & Have it. But a little. \\
\hline
\end{tabular}

Analysis of students in this study is a study of students' characteristics, including intellectual aspects, the language of students, learning motivation, and age of students. Analyze the intellectual development of students to consider in the preparation of the level of difficulty of the problem in the teaching material to be developed. Furthermore, in analyzing the language development of students, it is used to consider the preparation of language in teaching materials. While analyzing students' motivation is used to design teaching materials that make students motivated in learning.

\section{Design Stage}

Based on the analysis at the defining stage, reading teaching materials were used using DRTA strategies for fourth-grade elementary school students. The teaching materials that have been designed through developing instructional materials begin with the design of RPP. The drafting of the RPP is carried out systematically, which contains the components of writing the RPP listed in the Minister of National Education Regulation No. 41 concerning process standards and following the steps in preparing the RPP. Learning activities are designed to be adjusted using the DRTA strategy. RPP is also equipped with assessment guidelines such as observation sheets, assessment rubrics, and evaluation questions. 
Based on the analysis of SK and KD, competency achievement indicators were born, divided into 3 learning with an allocation of $4 \times 35$ minutes each used for one meeting. Each learning is developed by looking at three main activities: the initial activities, core activities, and final activities. The material developed in the RPP is to find the main idea by reading at a glance. RPP compiled using DRTA.

Teaching materials developed are adapted to the development characteristics of students. Teaching materials on teaching materials are developed referring to the results of the analysis of SK and $\mathrm{KD}$ and the indicators that have been formulated. The specifications of instructional materials developed are as follows: (1) Designed with a purple background, fool color headers and footers, (2) instructional materials are made using Microsoft word 2010 with the help of shapes and photoshop, (3) using font Tahoma, writing size 14, The reason for using font size 14 is to make it easier for students to read because the writing is quite large and clear and (4) teaching materials are equipped with exercises.

The format and preparation of these teaching materials are modified from the structure of teaching materials according to the Ministry of National Education, which consists of (1) cover, (2) preface, (3) table of contents, (4) instructions for use, (5) concept maps, (6) competence to be achieved, (7) assignments, (8) work instructions, (9) bibliography. The cover of the teaching material is shown in the picture below.

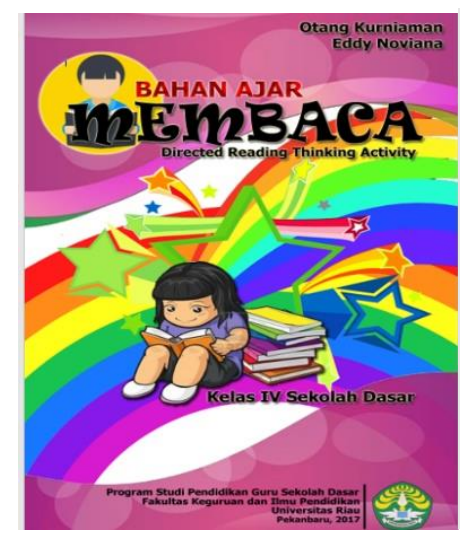

(a)

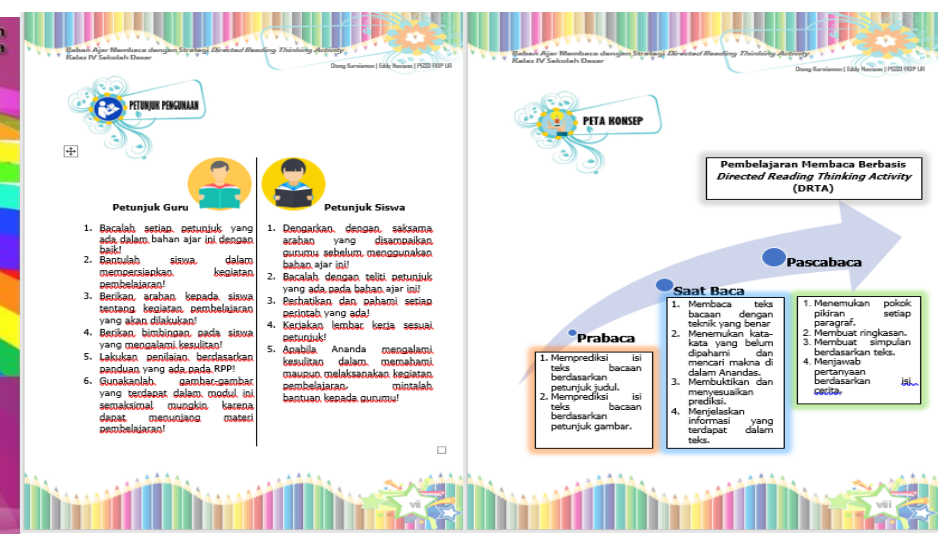

(b) (c)

\section{Figure 2. (a) Cover Of Teaching Materials; (b) Instructions In Teaching Materials; (c) Concept Maps}

To facilitate the teaching process, a concept map is needed to know and understand the learning activities carried out in each stage of reading comprehension learning. Concept maps are general descriptions of the stages of reading comprehension learning activities using DRTA strategies. These stages include pre-read, read, and post-read. This teaching material design is only a preliminary stage by presenting the teacher's initial concept. The next step is by making tasks predicting reading by using the DRTA strategy (Directed Reading Thinking Activity Strategy) with the following learning steps. The teacher writes the story's title on the board. Then the teacher tells a student to read the title. Then students have the opportunity to make predictions. It will be seen in the picture below. 


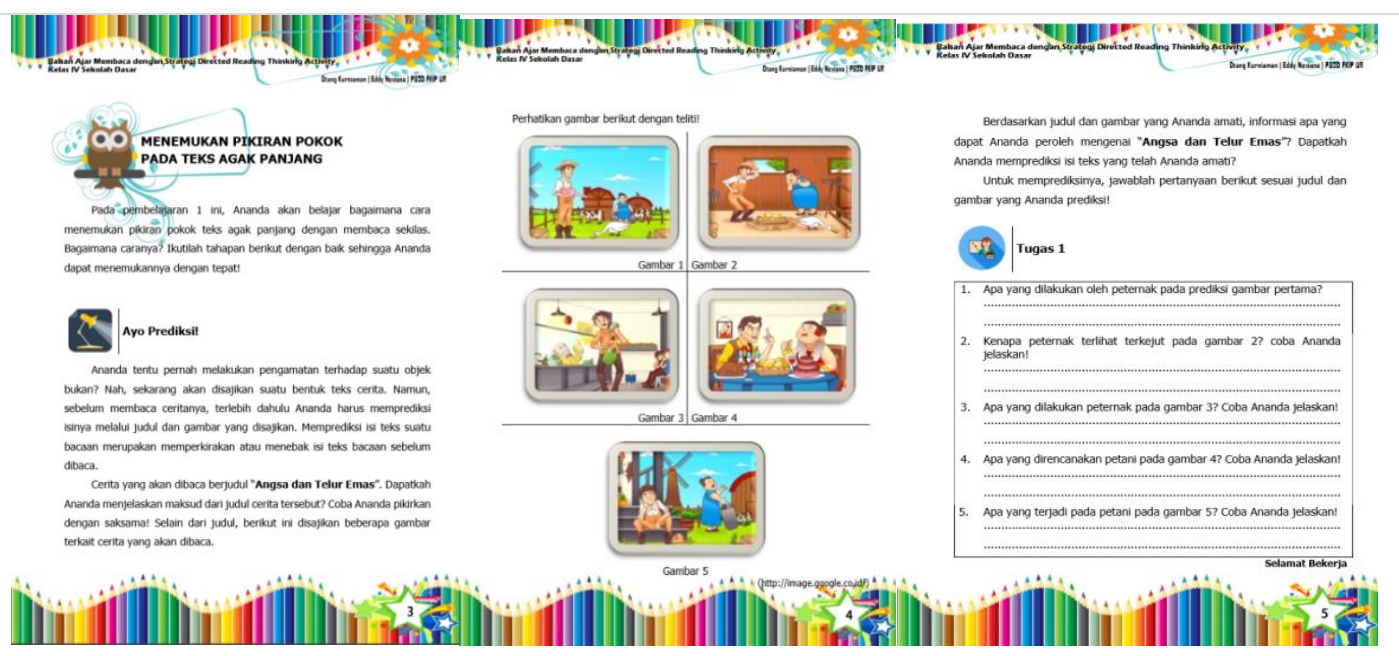

Figure 3. Reading Prediction

The teacher asks students to pay attention to the series drawing carefully. Next, the teacher tells students to pay attention to one of the pictures and asks students what exactly happened to the picture. The teacher tells students to read the reading section of the picture that has been predicted. When students read the first part of the story, the teacher directs a discussion by asking questions. Then the teacher told students who were convinced that the predictions were correct to read aloud in front of the class part of the reading that supported their predictions. Other students can respond. In the learning process with the DRTA strategy (Directed Reading Thinking Activity), the teacher conducts guidance to students. This is in line with Rahim's opinion (2009), which states that teachers observe children when they read to diagnose difficulties and offer assistance when students find it challenging to interact with the reading material.

\section{Stage Develop}

This development phase includes the validation of teaching materials and RPP. Then the product is tested to see the practicality and effectiveness of teaching materials that have been developed. Validation testing is by validating teaching materials by experts and practitioners and then revised. The teaching material becomes valid, practical, and effective, so it is suitable for use in the learning process. The instructional material designed is then validated by the validator. Three validators carried out validation from universities and three from elementary school teachers. In this activity, experts and practitioners are asked to assess the teaching materials that have been made. Assessment includes content, presentation, and language. The validator is asked to provide an assessment and suggestions for improvements to the RPP and the instructional materials that have been designed.

Table 2. Results of RPP Validation for Aspects of Learning Objectives

\begin{tabular}{clcc}
\hline No & \multicolumn{1}{c}{ Rated Aspect } & Average \% & Category \\
\hline 1. & $\begin{array}{l}\text { The formulation of learning objectives does not } \\
\text { lead to multiple interpretations }\end{array}$ & 92 & Very Valid \\
\hline 2. & $\begin{array}{l}\text { The formulation of complete learning objectives } \\
\text { meets the criteria }\end{array}$ & 100 & Very Valid \\
$\begin{array}{l}\text { A }=\text { Audience } \\
\mathrm{B}=\text { Behavior }\end{array}$ & & \\
& $\begin{array}{l}\text { C } \text { Condition } \\
\text { D = Degree }\end{array}$ & & \\
\hline 3. & $\begin{array}{l}\text { Formulation of sequential learning goals logically } \\
\text { from the easy to the difficult }\end{array}$ & 92 & Very Valid \\
\hline & Average & 94 & Very Valid \\
\hline
\end{tabular}

Based on table 2, after the figures are analyzed, it can be seen that the three statements on the aspects of formulating learning objectives have a range of values between 92 s.d. 100, which are in the very valid category. In comparison, the average validity aspect of the formulation of learning objectives is 94 with very valid categories. It means that the learning objectives that have been formulated have met good criteria, which are under the learning indicators, have met the $\mathrm{ABCD}$ criteria, and have been 
sorted from easy to difficult. The next aspect assessed is teaching material. Validation results for aspects of teaching materials can be seen in the following table.

Table 3. Results of RPP Validation for Aspects of Learning Material

\begin{tabular}{llccc}
\hline No & \multicolumn{2}{c}{ Rated Aspect } & Average \% & Category \\
\hline 1. & Under SK, KD, and indicators to be achieved & 100 & Very Valid \\
\hline 2. & $\begin{array}{l}\text { Teaching materials are under student } \\
\text { characteristics }\end{array}$ & 100 & Very Valid \\
\hline & Average & 100 & Very Valid \\
\hline
\end{tabular}

Table 3 shows that the range of values for each statement is 100, which is in the very valid category after the numbers are analyzed. Thus the average overall validity score from the aspect of teaching material is 100, with a very valid category. Based on this, it can be concluded that teaching materials are under SK, KD, indicators, and characteristics of students. The aspects that are assessed further are aspects that are reviewed from the source and learning media.

\section{Stage Disseminate}

The process of reading skills assessment is done using an assessment rubric. The assessed aspects are some student skills, from predicting reading activities, reading techniques, filling in the meaning of words that have not been understood, writing down the main contents of the reading text, and summarizing the summary of the reading contents. In summary, the assessment results in students' reading skills can be seen from the following table.

Table 4. Results of Assessment of Reading Prediction Process

\begin{tabular}{|c|c|c|c|c|c|c|}
\hline \multirow[b]{2}{*}{ No } & \multirow[b]{2}{*}{$\begin{array}{l}\text { Assessment } \\
\text { Indicator }\end{array}$} & \multicolumn{3}{|c|}{ Class Average Value (\%) } & \multirow[t]{2}{*}{ Average } & \multirow[t]{2}{*}{ Category } \\
\hline & & $\begin{array}{c}\text { Meeting } \\
1\end{array}$ & $\begin{array}{c}\text { Meeting } \\
2\end{array}$ & $\begin{array}{c}\text { Meeting } \\
\mathbf{3}\end{array}$ & & \\
\hline \multicolumn{7}{|c|}{$\begin{array}{l}\text { Reading } \\
\text { Stage }\end{array}$} \\
\hline 1. & Predict reading & 100 & 97.53 & 97.5 & 98.34 & Very Good \\
\hline \multicolumn{7}{|c|}{ Stage When Reading } \\
\hline & $\begin{array}{l}\text { Student reading } \\
\text { techniques }\end{array}$ & 100 & 100 & 100 & 100 & Very Good \\
\hline 3. & $\begin{array}{l}\text { Fill in the meaning } \\
\text { of words that are } \\
\text { not yet } \\
\text { understood }\end{array}$ & 85.2 & 87.7 & 87.7 & 86.87 & Very Good \\
\hline 4. & $\begin{array}{l}\text { Writing down the } \\
\text { main contents of } \\
\text { the reading text }\end{array}$ & 93.8 & 82.7 & 76.5 & 84.33 & Very Good \\
\hline \multicolumn{7}{|c|}{ Post-Read Stage } \\
\hline 5 & $\begin{array}{l}\text { Summarize the } \\
\text { summary of the } \\
\text { contents of the } \\
\text { reading text }\end{array}$ & 87.7 & 77.78 & 67.9 & $77 \cdot 79$ & Good \\
\hline Ave & age & $93 \cdot 34$ & 89.142 & 85.92 & 89.46 & Very Good \\
\hline
\end{tabular}

Table 4, after the figures are analyzed, shows that the process assessment of students' reading skills for each assessment indicator is 67.9 s.d. 100, which are included in the very good category. Assessment of the results of reading comprehension skills in learning 1 is 93.34 with a very good category. The assessment of the reading skills process at the 2nd meeting was 89.14 with very good categories. In contrast, reading comprehension skills at the 3rd meeting was 85.92 with very good categories. At the same time, the average reading process assessment is 89.46 , with a very good category. The three learning processes take place. The activities of students are very good at understanding and using teaching materials. Three main stages can be observed based on the table above, namely the pre-reading, reading, post-reading stages. 
The results of this study that teaching materials using the DRTA strategy in predicting reading are valid from the results of the assessment of experts and practitioners because reading is also a strategy. Effective readers use various reading strategies under the text and context to construct meaning when reading. This strategy varies according to the type of text and the purpose of reading (Munjiatun, Kurniaman, \& Meisal, 2015). DRTA is learning by emphasizing thoughts that make students predict reading (Somadayo et al., 2013). This teaching material cannot be separated from the learning steps of the DRTA strategy that emphasizes students in predicting reading.

Validation of teaching materials must be based on a learning plan that focuses on several aspects with the ABCD formula (Audience, Behavior, Condition, and Degree). It is very valid because the learning tools strongly influence the teacher's teaching style. In achieving effective strategies in teaching (Ismail, 2018), students' learning style and how the teacher teaches reading is important (Magfirah, 2018). Besides, teaching materials must contribute that can provide meaningful learning for students. Reading is very important in the world of education (Pahrurrazi, Kurniaman, \& Alpusari, 2018).

Based on the analysis of the practice questionnaire and interviews conducted with the teacher, it was concluded that teaching materials were easy to use by teachers and students (Kurniaman \& Zufriady, 2019; Noviana et al., 2019). It can be seen from the use of RPP that the teacher can implement well, although there are few obstacles in the use of time (Syafitri, 2018). However, this can be overcome at the next meeting. The readability of the teaching material used is straightforward and can be well understood, so it is beneficial for teachers in the learning process (Kurniaman \& Noviana, 2016). the purpose of students to read is often to obtain information about the subject they are studying, so reading for information content in class gives students an authentic purpose for reading (Lamri \& Hamzaoui, 2018). DRTA learning provides students' predictions in reading to help to understand. Choosing meaning or understanding is an active process, not a passive process, not just accepting, but connecting actual concepts in translating symbols presented in written form and interpreting them (İnce \& Gözütok, 2018). Reading comprehension is the act of thinking, constructing meaning by integrating information from the author with the reader's background knowledge (Kirmizi, 2010; Biringkanae, 2018).

\section{CONCLUSION}

This research focuses on the development of reading teaching materials using DRTA for grade IV elementary school. Based on the development, trial, and limited dissemination carried out. Researchers can conclude several things: Reading teaching materials using the DRTA strategy in the form of RPP and teaching materials produced in this development research are very valid in terms of content and construct. The lesson plan and teaching materials produced in this development research can be stated practically in terms of implementation and usage. Reading teaching materials using the DRTA strategy in the form of RPP and teaching materials produced in this development research has been declared effective for student reading skills.

\section{REFERENCES}

Al Odwan, T. A. A. (2012). The Effect of the Directed Reading Thinking Activity through Cooperative Learning on English Secondary Stage Students' Reading Comprehension in Jordan. International Journal of Humanities and Social Science, 2(16), 138-151.

Abi, M., \& Kömür, S. (2018). Tracing the Changes in Reading Scores and Learning Style Preferences through Reading Strategy Training. Eurasian Journal of Applied Linguistics, 4(2), 213-237. doi: $10.32601 /$ ejal.464121.

Biringkanae, A. (2018). The Use of SQ3r Technique in Improving Students`Reading Comprehension. ELS Journal on Interdisciplinary Studies on Humanities, 1(2), 218 - 225.

Hamzah, \& Mohamad, N. (2012). Belajar dengan Pendekatan PAILKEM : Pembelajaran, Aktif, Inovatif, Lingkungan, Menarik. Jakarta: Bumi Aksara

Hasan, A. (2017). The Effect of Directed Reading Thinking Activity (DRTA) Method on Students' Reading Comprehension for State Islamic Senior High School. Journal of English and Arabic Language Teaching, 8 (2), pp. 140-148.

Heriyawati, D. F., Saukah, A., \& Widiati, U. (2018). Working memory capacity, content familiarity, and university EFL students' reading comprehension. Indonesian Journal of Applied Linguistics, 8(1), 21-27 . doi: 10.17509/ijal.v8i1.11458. 
Harrington, M., \& Sawyer, M. (1992). L2 working memory capacity and L2 reading skill.Studies in Second Language Acquisition, 14, 25-38.

Ismail, M. (2018). The Use of Directed Reading Thinking Activity (Drta) to Improve Students Reading Comprehension of the First Grade of SMK Pembangunan Kota Ternate. Langua - Journal of Linguistics, Literature, and Language Education, 1(1), 42- 48.

İnce, M., \& Gözütok, F. D. (2018). Effect of Parental Education and Home Educational Resources to Students' Results of PISA Reading Skills Test. Elementary Education Online, 17(2), pp. 947-958. doi 10.17051/ilkonline.2018.419346.

Kurniaman, O., \& Noviana, E. (2017). Implementation of DRTA (Directed Reading Thinking Activity) Strategy on Reading Comprehension Skill Student Class V Muhammadiyah Elementary School 6 Pekanbaru. Proceeding of The 1st UR International Conference on Educational Sciences. 619-623. Kurniaman, O., Charlina., \& Noviana, E. (2018). Implementation DRTA Strategi for Elementary School. Beau Bassin: Lambret Academic Publishing.

Kurniaman, O., Noviana, E., Charlina., S.B. Simulyasih, N., Handayani, N. D., Sofyan, N. S., Zufriady., \& Septyanti, E. (2018). Why Should Primary Teachers Develop Learning Material by Directed Reading Thinking Activity (DRTA) Strategy?: 4-D Model. Advanced Science Letters, 24(11), 83898391. DOI: https://doi.org/10.1166/asl.2018.12570.

Kurniaman, O., Zufriady., Noviana, E., \& Afendi, N. (2018). Development of Teaching Materials for Reading Comprehension Skills Using the Graphic Organizer Media. Proceeding of the 2nd URICES, 2018, Pekanbaru, Indonesia, 385-390.

Kirmizi F.S. (2010). Relationship between Reading Comprehension Strategy use and daily free Reading time. Journal of Procedia Social and Behavioral Sciences, 2, 4752 - 4756.

Kurniaman, O., \& Noviana, E. (2016). Metode Membaca SAS (Struktural Analitik Sintetik) dalam Meningkatkan Keterampilan Membaca Permulaan di Kelas I SDN 79 Pekanbaru. Jurnal Primary: Pendidikan Guru Sekolah Dasar, 5(2), 149- 157.

Kurniaman, O., \& Zufriady. (2019). The Effectiveness of Teaching Materials for Graphic Organizers in Reading in Elementary School Students. Journal of Educational Sciences, 3(1), 48-62.

Kurniaman, O., Noviana, E., Hermita, N., \& Charlina, C. (2019). Pengaruh Strategi Membaca Direct Reading Thinking Activity (DRTA) Terhadap Siswa Sekolah Dasar. SEJ (School Education Journal), 9(3), 221-230.

Lally, C. (1998). Friend or foe: The use of direct object pronouns by native English speakers in both English and French. Reading Improvement, 35(1), 31-37.

Lu, Z., \& Liu, M. (2015). An investigation of Chinese university EFL learner's foreign language reading anxiety, reading strategy use and reading comprehension performance. Studies in Second Language Learning and Teaching, 5(1), 65-85. doi: 10.14746/ssllt.2015.5.1.4.

Lamri, C. E. \& Hamzaoui, H. (2018). Developing ELP Students' reading skills through a blended learning approach. Eurasian Journal of Applied Linguistics, 4(2), 389-407. doi: 10.32601/ejal.464204.

Mulyatiningsih. 2011. Metode Penelitian Terapan Bidang pendidikan. Bandung: Alfabeta.

Miyake, A., \& Friedman, N. P. (1998). Individual differences in second language proficiency: Working memory as language aptitude. In A. F. Healy \& L. E. Bourne (Eds.), Foreign language learning: Psycholinguistic studies on training and retention (pp. 339-364). Mahwah, NJ: Erlbaum.

Munjiatun., Kurniaman, O., Meisal, U. (2015). Kemampuan Mahasiswa PGSD FKIP UR dalam Keterampilan Membaca Pemahaman. Jurnal Primary: Pendidikan Guru Sekolah Dasar, 4(1). 1220.

Magfirah, T. (2018). Students' reading and listening comprehension based on their learning styles. International Journal of Education, 10(2), 107-113. doi: http://dx.doi.org/.

Nurdiyanti, E. \& Suryanto, E. (2010). Pembelajaran Literasi Mata Pelajaran Bahasa Indonesia pada Siswa Kelas V Sekolah Dasar. Journal PAEDAGOGIA 13(2): 115-128. 
Nazurty., Rustam., Priyanto., Nurullaningsih., Pratiwi, A., Sarmandan., Habibi, A., Mukminin, A. (2019). Learning Strategies in Reading: The Case of Indonesian Language Education Student Teachers. Universal Journal of Educational Research 7(11), 2536-2543. DOI: 10.13189/ujer.2019.071133.

Noviana, E., Kurniaman, O., Munjiatun., Sismulyasih Sb, N., \& Nirmala, S. D. (2019). Why Do Primary School Students Need Disaster Mitigation Knowledge? (Study Of The Use Of Koase Comics In Primary Schools). International Journal Of Scientific \& Technology Research, 8 (11). 216-221.

Putra, N. 2015. Research and Development, Penelitian dan Pengembangan: Suatu Pengantar. Jakarta: Raja Grafindo Persada.

Rahim, F. (2009). Pengajaran Membaca di Sekolah dasar. Jakarta: Bumi Aksara.

Pahrurrazi., Kurniaman, O., \& Alpusari, M. (2018). Analisis Minat Baca Siswa di Perpustakaan SDN 37 Pekanbaru. Jurnal Pajar (pendidikan dan Pengajaran), 2(6), 872-876.

Sakhiyya, Z., Agustien, H. I. R., \& Pratama, H. (2018). The reconceptualisation of knowledge base in the pre-service teacher education curriculum: Towards ELF pedagogy. Indonesian Journal of Applied Linguistics, 8(1), 49-56. doi: 10.17509/ijal.v8i1.11464.

Sugiyono. 2015. Metode Penelitian Kuantitatif Kualitatif dan R \& D. Bandung: Alfabeta.

Somadayo, S., Slamet, S. Y., Nurkamto, J., Suwandi, S. (2013). The Effect of Learning Model Drta (Directed Reading Thingking Activity) Toward Students' Reading Comprehension Ability Seeing from Their Reading Interest. Journal of Education and Practice, 4(8). 115- 122.

Saito, Y., Horwitz, E., \& Garza, J. (1999) Foreign Language Reading Anxiety. The Modern Language Journal,83, 202-218.

Syafitri, N. (2018). The Correlation Between Lecturers' Teaching Styles and Students' Reading Habit Towards Reading Comprehension. ELS Journal on Interdisciplinary Studies on Humanities, 1(1), 96-102. http://journal.unhas.ac.id/index.php/ijsh.

Septyanti, E., Kurniaman, O., \& Charlina, C. (2020). Development Of Interactive Media Based On Adobe Flash In Listening Learning For University Student. International Journal Of Scientific \& Technology Research, 9(01), 74-77. 